Evidence-based

speech-language

pathology and audiology

Fonoaudiologia

\section{Baseada em Evidências}

Raissa Gomes Fonseca Moura ${ }^{1}$ Daniele Andrade Cunha ${ }^{2}$ Ana Carolina de Lima Gusmão Gomes² Hilton Justino da Silva ${ }^{2}$

Keywords

Smell

Child

Diagnosis

Olfactory disorders

Olfactory perception

Descritores

Olfato

Criança

Diagnóstico

Transtornos do olfato

Percepção olfatória

Correspondence address:

Raissa Gomes Fonseca Moura

Secretaria do Programa de Pós-Graduação

em Saúde da Comunicação Humana da

Universidade Federal de Pernambuco

Avenida Artur de Sá, s/n, Cidade

Universitária, Recife (PE), Brasil,

CEP: 50670-420.

E-mail: raissa_gfm@hotmail.com

Received: 05/02/2013

Accepted: 11/12/2013

CoDAS 2014;26(1):96-101

\section{Quantitative instruments used to assess children's \\ sense of smell: a review article}

\section{Instrumentos quantitativos para avaliação do olfato na população infantil: artigo de revisão}

\begin{abstract}
Purpose: To systematically gather from the literature available the quantitative instruments used to assess the sense of smell in studies carried out with children. Research strategy: The present study included a survey in the Pubmed and Bireme platforms and in the databases of MedLine, Lilacs, regional SciELO and Web of Science, followed by selection and critical analysis of the articles found and chosen. Selection criteria: We selected original articles related to the topic in question, conducted only with children in Portuguese, English, and Spanish. We excluded studies addressing other phases of human development, exclusively or concurrently with the pediatric population; studies on animals; literature review articles; dissertations; book chapters; case study articles; and editorials. Data analysis: A book report protocol was created for this study, including the following information: author, department, year, location, population/sample, age, purpose of the study, methods, and main results. Results: We found 8,451 articles by typing keywords and identifiers. Out of this total, 5,928 were excluded by the title, 2,366 by the abstract, and 123 after we read the full text. Thus, 34 articles were selected, of which 28 were repeated in the databases, totalizing 6 articles analyzed in this review. Conclusion: We observed a lack of standardization of the quantitative instruments used to assess children's sense of smell, with great variability in the methodology of the tests, which reduces the effectiveness and reliability of the results.
\end{abstract}

\section{RESUMO}

Objetivo: Levantar na literatura, de forma sistemática, os instrumentos quantitativos utilizados para a avaliação do olfato em estudos com crianças. Estratégia de pesquisa: O presente estudo incluiu pesquisa nas plataformas Pubmed e Bireme e nas bases de dados MedLine, Lilacs, SciELO regional e Web of Science, seguindo etapas de seleção e análise crítica dos periódicos encontrados e escolhidos. Critérios de seleção: Foram selecionados artigos originais relacionados ao tema, realizados somente com a população infantil nas línguas portuguesa, inglês e espanhol. Foram excluídos estudos abordando outras fases do desenvolvimento humano, exclusivamente, ou concomitantemente com a população pediátrica; estudos com animais; artigos de revisão de literatura; dissertações; capítulos de livros; artigos de estudo de caso e editoriais. Análise dos dados: Foi criado um fichamento protocolar para este estudo contemplando os seguintes pontos: autor, departamento, ano, local, população/amostra, idade, objetivo do estudo, métodos utilizados e resultados principais. Resultados: Foram encontrados 8.451 artigos a partir da busca de descritores e termos livres. Desse total, 5.928 foram excluídos pelo título, 2.366 pelo resumo e 123 pela leitura do texto completo, sendo selecionados 34, dos quais 28 estavam repetidos nas bases de dados. Ao final, seis artigos foram analisados nesta revisão. Conclusões: Foi observada ausência de padronização dos instrumentos quantitativos utilizados para a avaliação do olfato na população infantil, com grande variabilidade na metodologia dos testes, diminuindo, portanto, a efetividade e a confiabilidade dos resultados encontrados.

Study carried out at the Graduate Program in Health of Human Communication, Department of Speech-language Pathology and Audiology, Universidade Federal de Pernambuco - UFPE - Recife (PE), Brazil.

(1) Universidade Federal do Rio Grande do Norte - UFRN - Natal (RN), Brazil.

(2) Universidade Federal de Pernambuco - UFPE - Recife (PE), Brazil.

Financial support: Pernambuco Research Foudantion (FACEPE) and National Council for Scientific and Technological Development (CNPq - process n. 475641/2011-6).

Conflict of interests: nothing to declare. 


\section{INTRODUCTION}

Smelling is a chemosensory function performed by the olfactory system ${ }^{(1,2)}$ of extreme importance for the survival of living creatures. In addition to enabling interaction with the environment through odor perception, it also aids in food search, in taste perception, and in the identification of dangerous situations.

Alterations in this sense may result in significant daily losses and risks ${ }^{(1,3)}$. In order for smells to be detected and later discriminated, the olfactory system must be functioning adequately. When this system does not function as a whole or there are mechanical impediments in areas involved with olfactory functions, some individuals, such as those with allergic rhinitis, nasal obstructions ${ }^{(4,5)}$, Alzheimer's or Parkinson's disease, epilepsy, and depression ${ }^{(6)}$ or those submitted to total laryngectomy ${ }^{(7,8)}$, may complain about sensing and differentiating smells. Several methods to assess the sense of smell have been developed, with the purpose of quantifying these possible difficulties and alterations.

In children, this assessment is usually conducted with methods that vary according to the applicability and eligibility of the instruments. Moreover, the available tests are not applied exclusively to this population and are also valid for other stages of human development. Quantitative instruments are the most commonly used in all stages.

These instruments can be objective, such as the electro-olfac$\operatorname{togram}^{(9)}$ and the Sniff magnitude test ${ }^{(10,11)}$, or subjective, such as the Sniff Sticks test battery ${ }^{(12)}$, the T\&T olfactometric test ${ }^{(13)}$, the smell threshold test ${ }^{(14)}$, and the brief smell identification test ${ }^{(15)}$. This variety prompted us to research, by means of reviewing the literature, the rules adopted to choose and to use quantitative instruments that assess children's sense of smell.

\section{PURPOSE}

The purpose of this study was to systematically gather, from the literature, the quantitative instruments used to assess the sense of smell in studies carried out with children by identifying and verifying the frequency of use and the selection criteria adopted to define their applicability and efficacy in this population.

\section{RESEARCH STRATEGY}

In order to formulate this literature review, we sought to answer the following questions: What are the quantitative instruments used to assess the sense of smell among children? How are they selected? How frequently are they used? Are they effective? Do they adequately characterize children with regard to olfactory alterations?

Based on these questions, the bibliographical search was carried out by assessing the platforms Pubmed and Bireme and the databases MedLine, Lilacs, regional SciELO (from August to September 2013) and Web of Science (April 2013).

We used descriptors (DeCS and MeSH) to retrieve topics from the scientific literature and open terms (OT) not found in the DeCS and MeSH but also relevant to the study. We utilized the following crossings in English, Portuguese, and Spanish: smell (DeCS/MeSH) AND child (DeCS/MeSH); smell (DeCS/MeSH) AND assessment (OT); smell (DeCS/MeSH) AND diagnosis (DeCS/MeSH); smell disorders (DeCS/MeSH) AND child (DeCS/MeSH); smell disorders (DeCS/MeSH) AND diagnosis (DeCS/MeSH); smell disorders (DeCS/MeSH) AND assessment (OT).

The survey was carried out independently by two researchers, in accordance with the inclusion and exclusion criteria. The conflicting points were later solved by a third evaluator. A specific time period was not established for when the studies were published.

\section{SELECTION CRITERIA}

As inclusion criteria, we selected original articles by scholars who used quantitative instruments to assess smell only among children (individuals between 0 and 11 years and 11 months of age, according to Law 8069 of July 13, 1990, which discourses about Brazil's Child and Adolescent Statute). The manuscripts were published in Portuguese, English, and Spanish.

We excluded original articles that made no reference to the topic of this review in the title, abstract, or full text; studies focused exclusively on other stages of human development or those in which children were assessed along with adolescents, adults, or elderly people; studies with animals; and literature reviews, dissertations, book chapters, case studies, and editorials.

On the Pubmed database, we activated filters concerning species (humans), language (English, Portuguese, and Spanish), and age (6-12 years; birth to 18 years; birth to 1 month; birth to 23 months; $1-23$ months; $2-5$ years). No research filters were applied when accessing MedLine, Lilacs, SciELO, and Web of Science.

\section{DATA ANALYSIS}

Using the keywords and OT defined previously, we identified and selected the articles to be analyzed from the databases of choice.

First, we read the titles of the papers. Then, we read the abstracts of those selected based on the relevance of the title. In case these articles were in accordance with the pre-established inclusion criteria, they were analyzed in their entirety, following a protocol created for this purpose.

The papers that were finally selected were those that fulfilled all the eligibility criteria described above, thus enabling us to answer the questions posed in this review.

The data contained in the articles of interest were minutely analyzed by means of a filing protocol created for the present study, with the following information: author, department, year, location, population/sample, age, purpose of the study, methods used, and the main results.

Considering what was relevant in each article, we present the data here through tables and figures, with the purpose of facilitating visualization and comprehension during the presentation and discussion of the results. 


\section{RESULTS}

Our search yielded 8,451 articles. Out of this number, 5,928 were excluded based on the title, 2,366 based on the abstract, and 123 were excluded upon reading of the text in full. Therefore, 34 articles were selected according to the inclusion and exclusion criteria. However, 28 of them were repeated in the databases, which resulted in six works being analyzed in this review (Figure 1).

Upon verification of our selection (Table 1), we found that the studies were highly diverse, which prevented the conduction of statistical analyses (meta-analysis), especially because the sample, the population's age, and the purpose of each study varied. Nevertheless, in spite of these divergences, important reflections and conclusions can be drawn from this review.

Authors linked to medicine departments ${ }^{(16-19)}$ are the ones who most frequently conduct studies on smell among children. We highlight the lack of studies coordinated and carried out by speech-language pathologists, even though this sense is considerably important in the feeding process and for an individual's overall development. With this concern in mind, studies on smell and taste among mouth-breathing children are being developed by the research group Pathophysiology of the Stomatognathic System, directed by speech-language pathologists at Universidade Federal de Pernambuco, Brazil.

Research studies on the quantification of the sense of smell with an exclusive focus on the pediatric population appeared in the $1990 \mathrm{~s}^{(20)}$ and intensified from 2005 onward $^{(16-19,21)}$. It is supposed that this late appearance of studies with purposes related to olfactory conditions in children is due to the fact that auditory and visual alterations have more noticeable negative consequences on this population than chemosensory disorders. Furthermore, this can be explained by the difficulty of applying reliable quantitative tests on children. However, there is concern about this aspect currently, given the importance of the sense of smell for the whole feeding process of an individual, as well as for self-defense in dangerous situations.

France ${ }^{(16,21)}$ is the leading country in studies on the sense of smell in children. It is important to highlight the lack of studies on the characterization and assessment of this function in South

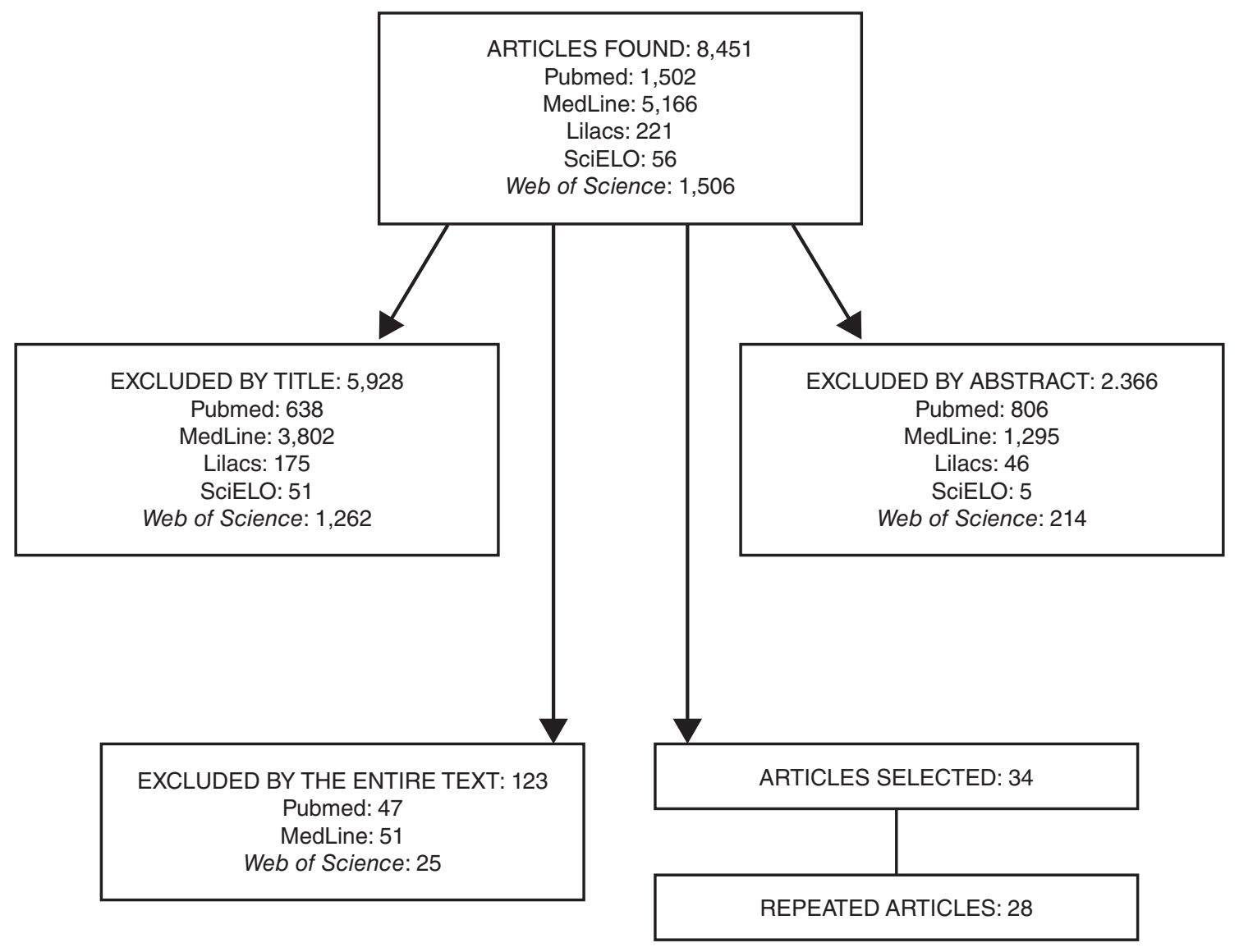

ARTICLES ANALYZED: 6

Figure 1. Fluxogram of the number of articles found and selected after the application of inclusion and exclusion criteria 
Table 1. Results of the studies selected, according to the variables studied

\begin{tabular}{|c|c|c|c|c|c|c|c|}
\hline Author & Department & Year & Location & Population/ Sample & Age & Purpose & Methods used \\
\hline $\begin{array}{l}\text { Rinck, F; } \\
\text { Barkat- } \\
\text { Defradas, M; } \\
\text { Chakirian, A; } \\
\text { et al.16 }\end{array}$ & Neurosciences & 2011 & $\begin{array}{l}\text { Villeneuve- } \\
\text { le's- } \\
\text { Maguelone, } \\
\text { France }\end{array}$ & $\begin{array}{c}15 \text { native, } \\
\text { French-speaking, } \\
\text { monolingual } \\
\text { children }\end{array}$ & $\begin{array}{l}\text { Between } \\
04 \\
\text { and } 05 \\
\text { years. }\end{array}$ & $\begin{array}{l}\text { To investigate olfactory } \\
\text { changes during } \\
\text { language development }\end{array}$ & $\begin{array}{l}12 \text { odors were diluted in mineral } \\
\text { oil and presented on paper strips } \\
(10 \mathrm{~cm} \text { long, } 1 \mathrm{~cm} \text { wide). During } \\
\text { the procedure, the children were } \\
\text { asked two questions: "Do you } \\
\text { like this smell or not?" and "What } \\
\text { smell is this?" }\end{array}$ \\
\hline $\begin{array}{l}\text { Monnery- } \\
\text { Patris, S; } \\
\text { Rouby, C; } \\
\text { Nicklaus, } \\
\text { S.21 }\end{array}$ & Not informed & 2009 & France & $\begin{array}{l}146 \text { children ( } 71 \\
\text { boys and } 75 \text { girls) } \\
\text { enrolled in public } \\
\text { schools }\end{array}$ & $\begin{array}{l}\text { Between } \\
04 \text { and } \\
12 \text { years. }\end{array}$ & $\begin{array}{l}\text { To assess olfactory } \\
\text { sensitivity and } \\
\text { identification in early-age } \\
\text { children, as well as } \\
\text { investigate the role of } \\
\text { verbal skills development } \\
\text { in smell identification } \\
\text { performance }\end{array}$ & $\begin{array}{l}\text { The children were presented } \\
\text { with } 16 \text { smells diluted in mineral } \\
\text { oil with the aid of representative } \\
\text { images (revised version of the } \\
\text { olfactory test devised by Rouby } \\
\text { et al., 1997)26. }\end{array}$ \\
\hline
\end{tabular}

\begin{tabular}{|c|c|c|c|c|c|c|c|}
\hline $\begin{array}{l}\text { Armstrong, } \\
\text { JE; } \\
\text { Hutchinson, } \\
\text { I; Laing, } \\
\text { DG.et al. } 17\end{array}$ & Medicine & 2007 & $\begin{array}{l}\text { Sydney, } \\
\text { Australia. }\end{array}$ & $\begin{array}{l}34 \text { children (13 } \\
\text { boys and } 21 \text { girls) } \\
\text { selected from a } \\
\text { local school. }\end{array}$ & $\begin{array}{c}\text { Between } \\
6 \text { and } 9 \\
\text { years. }\end{array}$ & $\begin{array}{l}\text { To determine whether } \\
\text { facial Electromyography } \\
\text { can provide reliable } \\
\text { answers about different } \\
\text { smell and taste stimuli, } \\
\text { and whether it is possible } \\
\text { to distinguish olfactory } \\
\text { and gustatory stimuli as } \\
\text { pleasant or unpleasant } \\
\text { by using EMG. }\end{array}$ & $\begin{array}{l}\text { Presentation of two odors } \\
\text { (one established as pleasant } \\
\text { and the other as unpleasant) } \\
\text { and facial control performed } \\
\text { by the activity of zygomatic } \\
\text { and lip elevator muscles using } \\
\text { Electromyography. }\end{array}$ \\
\hline
\end{tabular}

Hummel, T;

Bensafi, M; Nikolaus, J; et al. 18
146 children for a psychophysical test and 12 children for an electrophysiological assessment.
To describe changes that occur during olfactory Between information processing 03 and during child development 12 years. by establishing electrophysiological
Sniffin Sticks Test Battery (Test of identification of 12 smells).
The results showed that, at five years of age, children categorize odors as pleasant more frequently, and that this change was more significant as language production skills were developed further

Olfactory identification and sensitivity increased as schooling advanced, and smell identification performance was better among girls than boys. However, when verbal skills were However, when verbal skills were
controlled, gender differences disappeared, and only schooling differences remained.

Upon observation of the recordings concerning the zygomatic muscle, more than $90 \%$ of the children had responded to all olfactory stimuli, with response levels ranging from $97,1 \%$ to $100 \%$ for the odors

from $97,1 \%$ to $100 \%$ for the odors
used (unpleasant and pleasant, used (unpleasant and pleasant,
respectively). On the other hand, respectively). On the other hand, was more selective, as $94,1 \%$ of the children responded to the unpleasant odor, with less markedly reaction to the pleasant odor.

The statistical analysis did not indicate any significant changes brought by age concerning odor threshold and discrimination only in relation to odor identification. The sex factor did not influence the results, and there was no interaction between age and gender. The group with 3 to 5 with 3 to 5 -yearciculty to comp difficulty to complete the test, and the group with 6-year-olds presented advanced olfactory development, according to the results.

The olfactory function (nasa and retronasal) of the study group before the operation was significantly reduced in comparison to the results of the control group. After the operation, control group. After the operation,
retronasal discrimination improved significantly compared to nasal discrimination. The authors suggest a marked association between adenoid hypertrophy and retronasal discrimination.

Statistically significant differences were found concerning the individuals' search, for a prolonged period of time, for the mothers' nipple odor (main odor stimulus) than for the control block devoid of odor substances, without any differences between the sexes. Statistically significant differences were found in the search for the were found in the search for the
smell of formula in comparison smell of formula in comparison
to the mothers' nipple smell, with differences concerning this search between the sexes. The majority of the babies evaluated took significantly longer when guided towards the smell of an unknown nipple than towards a formula with familiar smell.
America, and especially in Brazil, although there are Brazilian review articles in which scholars relate total laryngectomy to smell/taste alterations and assessments and the rehabilitation of these functions ${ }^{(22,23)}$.

The population studied in the articles selected for this review was chiefly composed of healthy children ${ }^{(16-18,20,21)}$, probably because there are no normative standards that allow for comparisons between healthy and sick populations.

The samples were composed of 15 children $^{(16)}$ at least and 158 at the most ${ }^{(18)}$. We perceived, however, a larger amount of studies with samples of less than 100 individuals $^{(16,17,19,20)}$ and a higher prevalence of female children.

The age range varied significantly. While some authors studied newborns ${ }^{(20)}$, others focused on pre-school and school-aged children ${ }^{(16-19,21)}$. Thus, the age range varied between 12 days of post-uterine life ${ }^{(20)}$ and 12 years $^{(18,21)}$. This enabled us to contemplate, in this review, the entire age range defined as childhood by Law 8069 of July 13, 1990, which discourses about Brazil's Child and Adolescent Statute. This difference possibly occurred due to the 
necessity of obtaining proof with regard to different aspects of children's development, such as the influence of the sense of smell in language acquisition ${ }^{(16,21)}$, breastfeeding ${ }^{(20)}$, and memories and emotions evoked by environmental smells and family life ${ }^{(17,20)}$.

The aims of the studies varied from characterizing a population $^{(19-21)}$ to associating two points ${ }^{(16,18,21)}$ and substantiating the establishment of a given tool to assess the sense of smell in pediatric practice ${ }^{(17)}$. This variety of purposes makes it difficult to standardize assessment instruments and results in healthy populations, hindering comparisons among ill individuals and safe, early diagnoses in this population.

All the tests and instruments used to assess olfactory functioning in the studies included in this review are of a quantitative nature. However, the tests varied with regard to their application. Some scholars asked the children to identify ${ }^{(16,18,19,21)}$ or judge the pleasantness ${ }^{(16)}$ of odors presented to them; others quantified answers based on how long it took for the individuals to direct their bodies toward specific odors ${ }^{(20)}$ or data visualized in computer programs, such as the study ${ }^{(17)}$ in which electromyography was used to control the facial movements of certain muscles during exposure to pleasant and unpleasant odors.

The repeated use of the Sniffin Sticks test battery — an objective and commercially available standardized assessment method that presents 12 odors contained in sticks to the individual to be assessed - in two of the studies conducted $^{(18,19)}$ may be an indication that there is a path leading to the standardization of instruments to assess the sense of smell in children. This is mentioned because we noticed, in the process of this review, a lack of standardization and a broad variation concerning the use of specific tests aimed at children. Thus, the reliability of the works selected is hereby put into question.

It is important to highlight that the advancement in research already points to a path to be developed in search of the standardization of quantitative instruments that assess olfactory functioning in children from 0 to 12 years of age. For instance, in the studies analyzed here, all tests were psychophysical (composed of a standard physical stimulus and a standard psychic response), which means that all children were exposed to several smells diluted in mineral oil ${ }^{(16,21)}$. The concern about the standardization of instruments to assess children lies in the particularities of this population, such as cognitive, linguistic, and emotional development, factors that must be contemplated during the conception of assessment instruments that are specific to this age range.

In the instruments used in the studies analyzed, the method or utensil utilized to present odors varied. Scholars used paper strips ${ }^{(16)}$, pen-shaped tubes ${ }^{(18,19)}$, and odorized blocks or smells embedded in absorbent cloth contained in $15-\mathrm{mL}$ flasks ${ }^{(21)}$, for instance. The amount of smells presented did not follow any standardization either, varying between $2^{(17,20)}$ and $16^{(21)}$. The same is true of the choice of odors and exposure periods. Possibly, all these variations occurred with the purpose of adapting the assessment methods to the population's age.

Regarding the assessment instruments, we noticed the essential role of representative images that aid in elucidating olfactory and semantic memory and help the children to provide their answers with certainty. In one of the studies ${ }^{(21)}$ analyzed in this review, the authors adapted the assessment test of choice by presenting the children with four images and asking them to point to the one that corresponded to the odor in question; according to the scholars, this modification facilitates the retrieval of familiar smells. In works ${ }^{(24,25)}$ where photos or real images of the odors exposed were used, we observed better performances in the assessment of the sense of smell in children. Therefore, the application of these visual resources can confer reliability to tests and assessments of children's sense of smell. And, if the purpose of the assessment is to detect and discriminate odors and concentrations, nothing prevents their use as long as they are chosen in a judicious and balanced manner, without directing the children either to wrong or to right answers.

Last, the results varied in accordance with the aims of the studies. The majority had their hypotheses confirmed ${ }^{(16,17,19-21)}$; one was partially confirmed, as the authors did not find statistically significant associations regarding the detection and discrimination of odors by children of different ages, but only concerning the identification of smells ${ }^{(18)}$. Nevertheless, all stated the importance of early investigation through reliable means to diagnose olfactory conditions among children.

\section{CONCLUSION}

Assessing children's sense of smell is not an easy task due to the particularities of this age range. However, with the advancement of research and the interest of many professionals involved in this scenario, such as speech-language pathologists, occupational therapists, otorhinolaryngologists, and neurologists, good results can be achieved, especially with regard to the standardization of quantitative instruments and tests that are specific to this age range.

The review in question showed this possibility and the necessity of further detailed studies, with the purpose of stabilizing and standardizing quantitative instruments to assess children's sense of smell, as we observed, in the present study, a lack of standardization of these instruments concerning their application with children and a broad variation in the methodologies used to apply these tests, therefore lowering the effectiveness and reliability of the results found.

The achievement of this level of specificity in assessing children's sense of smell will guarantee reliable diagnoses and therapeutic plans based on accurate scientific evidence. In this sense, these same instruments can also be adequately used in speech therapy without the risk of factors such as the choice and quantity of odors, exposure period, and the method interfering with the process of (re)habilitation of the olfactory system. 
*RGFM was responsible for data collection, tabulation and analysis, as well as manuscript elaboration; DAC supervised data collection, tabulation and analysis, and the stages of manuscript elaboration and writing; ACLGG collaborated with data collection and tabulation; HJS was responsible for the study project and outline, and overall supervision of the stages of manuscript elaboration and writing.

\section{REFERENCES}

1. D’emery RA. Aplicação de análises estatística e neural para reconhecimento de sinais de odores. Recife: UFRPE, 2007, p. 191. (Dissertação de mestrado em Biometria - Departamento de Estatística e Informática, Universidade Federal Rural de Pernambuco).

2. Breer H. Sense of smell: recognition and transduction of olfactory signals. Biochem Soc Trans. 2003;31(1):113-6.

3. Rocha FMN, Ximenes Filho JA, Alvarenga EHL, Mello JF. Olfação revisão de literatura. Arq Int Otorrinolaringol. 2002;6(2). Disponível em: <http://www.internationalarchivesent.org/conteudo/acervo_port. asp?id=189>. Acesso em: 24 set. 2012.

4. Adant JP, Nelissen X, Demanez JP, Fissette J. Nasal obstruction: physiology, etiology and review. Rev Med Liege 1998;53(11):691-9.

5. Bonfils P, Le Bihan C, Landais P. Semiologic study of chronic perennial and permanent paranasal sinus dysfunction: prevalence of symptoms. Ann Otolaryngol Chir Cervicofac. 1998;115(4):177-88.

6. Heckmann JG, Lang CJ. Neurological causes of tastes disorders. Adv Otorhinolaryngol. 2006;63:255-64.

7. Welge-Luessen A, Kobal G, Wolfensberger M. Assessing olfactory function in laryngectomees using the Sniffin'sticks test battery and chemosensory evoked potentials. Laryngoscope. 2000;110:303-7.

8. Gouveia Sobrinho E, Carvalho M, Franzi S. Aspectos e tendências da avaliação da qualidade de vida de doentes com câncer da cabeça e pescoço. Rev Soc Bras Cancerol. 2001;4(15):1-7.

9. Wang L, Hari C, Chen L, Jacob T. Anew-non-invasive method for recording the electro-olfactogram using external electrodes. Clin Neurohysiology. 2004;115:1631-40.

10. Frank RA, Gesteland RC, Bailie J, Rybalsky K, Seiden A, Dulay MF. Characterization of the sniff magnitude test. Arch Otolaryngol Head Neck Surg. 2006;132:532-6.

11. Tourbier IA, Doty RL. Sniff magnitude test: relationship to odor identification, detection, and memory tests in a clinic population. Chem. Senses. 2007;32:515-23.

12. Hummel T, Sekinger B, Wolfe SR, Pauli E, Kobal G. "Sniffin Sticks": olfactory performance assessed by the combine testing of odor identification, odor discrimination and olfactory threshold. Chem Sens. 1997;22:39-52.

13. Takagi SF. Human olfaction. Tokyo: Univ Tokyo Press, 1989.

14. Doty RL. Odor threshold test administration manual. Haddon Heights: Sensonics Inc. 2000
15. Doty RL. The brief smell identification test $\mathrm{t}^{\mathrm{TM}}$ administration manual. New Jersey: Sensonics Inc. 2001

16. Rinck F, Barkat-Defradas M, Chakirian A, Joussain P, Bourgeat F, Venet $\mathrm{M}$ et al. Ontogeny of odor liking during childhood and its relation to language development. Chem Sens. 2011;36:83-91.

17. Armstrong JE, Hutchinson I, Laing DG, Jinks AL. Facial electromyography: responses of children to odor and taste stimuli. Chem. Sens. 2007;32:611-21.

18. Hummel T, Bensafi M, Nikolaus J, Knecht M, Laing DG, Schaal B. Olfactory function in children assessed with psychophysical and electrophysiological techniques. Behav brain res. 2007;180:133-8.

19. Konstantinidis I, Triaridis S, Triaridis A, Petropoulos I, Karagiannidis K, Kontzoglou G. How do children with adenoid hypertrophy smell and taste? clinical assessment of olfactory function pre and post-adenoidectomy. Int J Pediatr Otorhinolaryngol. 2005;69:1343-9.

20. Porter RH, Makin JW, Davis LB, Christensen KM. An assessment of the salient olfactory environment of formula-fed infants. Physiol Behav. 1991;50(5):907-11.

21. Monnery-Patris S, Rouby C, Nicklaus S, Issanchou S. Development of olfactory ability in children: sensitivity and identification. Wiley Periodicals. 2009.

22. Caldas ASC, Facundes VLD, Melo TMA, Dourado Filho MG, Pinheiro Júnior PF, Silva HJ. Alterações e avaliação das funções do olfato e do paladar em laringectomizados totais: revisão sistemática. J Soc Bras Fonoaudiol. 2011;23(1):82-8.

23. Caldas ASC, Facundes VLD, Silva HJ. Reabilitação das funções do olfato e do paladar em laringectomizados totais: revisão sistemática. Rev. CEFAC. 2012;14(2):343-9.

24. Fossey E. Identification of alcohol by smell among young children: an objective measure of early learning in the home. Drug Alcohol Depend.1993;34:29-35.

25. Noll RB, Zucker RA, Greenberg GS. Identification of alcohol by smell among preschoolers: evidence for early socialization about drugs occurring in the home. Child Dev. 1990;61:1520-7.

26. Rouby C, Gautier B, Chevalier G, Dubois D. Connaissance et reconnaissance d'une se'rie olfactive chez l'enfant pre'scolaire. Enfance. 1997;1:152-71.

27. Cernoch JM, Porter RH. Recognition of maternal axillary odors by infants. Child Dev. 1985;56:1593-8.

28. Macfarlane A. Olfaction in the development of social preferences in the human neonate. In: Parent-infant interaction. Ciba Found. Symp. New York: Elsevier. 1975;33:103-13.

29. Makin JW, Porter RH. Attractiveness of lactating females' breast odors to neonates. Child Dev. 1989;60:803-10.

30. Schaal B, Montagner H, Hertling E, Bolzoni D, Moyse A, Quichon R. Les stmulations olfactives dans les relations entre l'enfant et la mere. Reprod Nutr Dev. 1980;20:843-58.

31. Schleidt M, Genzcl C. The significance of mother's perfume for infants in the first weeks of their life. Ethol Sociobiol. 1990;11:145-54. 